\title{
Survei Minat Dan Motivasi Masyarakat Mengikuti Fun Race And Trail Run Di Masa New Normal Di Kawasan Pariwisata Sembalun Lombok Timur Nusa Tenggara Barat
}

\author{
Lalu Moh Yudha Isnaini ${ }^{1}$, Lalu Mariawan Alfarizi ${ }^{2}$, Andi Mulyan ${ }^{3}$ \\ lalumohyudhaisnaini@unu-ntb.ac.id \\ 123. Universitas Nahdlatul Ulama NTB, Indonesia,
}

\begin{abstract}
Abstrak. Olahraga rekreasi dilakukan sebagai bagian dari proses pemulihan kembali kesehatan dan kebugaran, oleh setiap orang, satuan pendidikan, lembaga, perkumpulan, atau organisasi olahraga, bertujuan untuk memperoleh kesehatan, kebugaran jasmani, kegembiraan dan membangun hubungan sosial. Penelitian ini bertujuan untuk mengetahui bagimanakah minat dan motivasi masyrakat mengikuti fun race dan trial run di daerah Sembalun Lombok Timur Nusa Tenggara Barat. Metode penelitian adalah survei dengan melakukan pendekatan deskriptif. Populasi penelitian ini adalah masyarakat yang mengikuti Fun race and trail run di kawasan pariwisata Sembalun Lombok Timur Nusa Tenggara Barat. Teknik sampling yang digunakan adalah accidental sampling banyaknya sampel adalah 50 orang. Teknik pengumpulan data menggunakan observasi, angket, wawancara, dan dokumentasi. Teknik analisis data yang digunakan adalah deskriptif kuantitatif. Berdasarkan hasil analisis data minat dan motivasi masyarakat mengikuti fun race and trial run di kawansan Sembalun Lombok Timur menunjukan hasil dengan kategori tinggi sebesar $81 \%$.
\end{abstract}

Kata kunci: Minat, Motivasi Fun Race And Trail Run.

\section{PENDAHULUAN}

Olahraga menjadi bagian hidup yang tak terpisahkan bagi manusia di muka bumi ini. Olahraga pada dasarnya mempunyai peran sangat strategis bagi upaya pembentukan dan peningkatan kualitas sumber daya manusia untuk pembangunan (Endrawan, 2017). Olahraga masyarakat dilakukan sebagai bagian dari proses pemulihan kembali kesehatan dan kebugaran, oleh setiap orang, satuan pendidikan, lembaga, perkumpulan, atau organisasi olahraga yang bertujuan untuk memperoleh kesehatan, kebugaran jasmani, dan kegembiraan, membangun hubungan sosial, dan melestarikan dan meningkatkan kekayaan budaya daerah dan nasional (Firdaus, 2019). Kesadaran akan makna strategis olahraga harus melalui perencanaan pembangunan yang berpihak pada kemajuan olahraga secara menyeluruh (Kodric, 2013). Olahraga memiliki berbagai potensi yang berisikan suatu semangat dan kekuatan untuk membangun, karena sebenarnya merupakan sense of spirit dari suatu proses panjang pembangunan itu sendiri. Olahraga harus dipandang sebagai tujuan sekaligus aset pembangunan (Kristiyanto, 2012), Rekreasi adalah kegiatan yang dilakukan untuk penyegaran kembali jasmani dan rohani seseorang (Kustiawan, 2018). Hal ini adalah sebuah aktivitas yang dilakukan seseorang selain pekerjaan. Kegiatan yang umum dilakukan untuk rekreasi adalah pariwisata, olahraga, permainan dan hobi. Kegiatan rekreasi umumnya dilakukan pada akhir pekan. Secara umum rekreasi dapat dibedakan dalam dua golongan besar, yaitu rekreasi pada tempat tertutup (indoor recreation) dan rekreasi di alam terbuka (outdoor recreation).

Olahraga dapat dilakukan dialam terbuka, namun karena keterbatasan waktu maka masyrakat banyak yang lebih memilih untuk berolahraga didaerah sekitar tempat tinggal (Lonsdale, 2014). Selama pandemi covid 19 masyarakat umumnya melakukan olahraga dirumah. Festival Fun race dan trail run merupakan acara pertama aktivitas olahraga pasca pandemi covid 19 yang diadakan di Nusa Tenggara Barat dalam rangka ulang tahun 
Pemerintah Lombok Timur. Kegiatan festival fun race dan trail run merupakan perlombaan lari dan sepeda yang dilakukan di daerah wisata Sembalun dengan lintasan yang menyuguhkan pemandangan alam dengan tetap menggunakan protokol kesehatan di dalam penyelenggaran lomba sehingga banyak diminati oleh masyarakat.

Event olahraga fun race dan trail run merupakan acara olahraga rekreasi lari dan bersepeda sambil menikmati pemandangan gunung rinjani. Kegiatan olahraga rekreasi fun race dan trail run diharapkan dapat berjalan terus menerus dan berkelanjutan dan dikembangkan dalam masa-masa tertentu dalam wilayah festival dan lomba yang dapat mempersaingkan seiring dengan potensi yang dimiliki sembalun sebagai daerah pariwisata serta dapat menjadi hiburan atau tontonan yang menarik. Perhatian yang perlu diutamakan adalah bagaimana event olahraga rekreasi pun dapat menjadi bernilai ekonomi (Wibowo, 2017). Prinsip keberlanjutan yang terprogram dengan baik yang bercorak tontonan atau hiburan yang dikemas dalam wujud ekonomi olahraga pariwisata akan menjadi sumber pendorong sesuatu kegiatan olahraga rekreasi yang menghasilkan. Demikian pula, mengelola waktu senggang (leisure time) dengan memanfaatkan olahraga rekreasi akan menjadi menarik manakala dapat menghasilkan sesuatu yang bernilai ekonomi, maksudnya adalah mendesain program olahraga rekreasi dalam masa pandemi covid 19 tertentu bagi kelompok masyarakat dalam perkumpulan atau sanggar dalam bentuk kegiatan seperti outbond, rekreasi olahraga sambil berwisata, hiking dan lain-lain.

Olahraga Rekreasi sejauh ini sudah dianggap sangat penting dalam kehidupan manusia,

semua lapisan masyarakat sudah menempatkan kegiatan rekreasi ini pada rating teratas dalam kegiatan sehari-hari mereka, bahkan tidak jarang ada yang sudah menjadwalkan kegiatan ini dan menjadi kegiatan wajib setiap minggunya. fun race and trail run di masa new normal dipandang penting karena dapat meningkatkan pertumbuhan ekonomi didaerah masing-masing bahkan rekreasi juga sangat berpengaruh pada pendapatan daerah dengan memanfaatkan tempat-tempat wisata untuk menarik pengunjung wisatawan (Rahmawati, 2020). Begitu pula dengan olahraga, olahraga tidak kalah pentingnya dengan rekreasi bahkan didalam olahraga bukan hanya dapat meningkatkan perekonomian suatu bangsa tapi juga ada ajang silaturahmi para peminat olahraga rekreasi. Jika olahraga dikelola dengan semaksimal mungkin maka ini akan menjdi batu loncatan untuk menuju persaingan global di kancah nasional dan internasional. Tujuan dalam penelitian ini mengetahui minat dan motivasi masyarakat mengikuti fun race dan trail run di kawasan pariwisata Sembalun Lombok Timur di masa new normal. Event olahraga fun race and trail run merukan alternatif bagi masyrakat Nusa Tenggara Barat untuk mengisi waktu lauang mereka pada akhir pekan sebagi salah satu sarana mereka untuk bisa menghilangkan kepenatan atas covid 19 selama beberapa bulan terakhir. Atas dasar itu maka penelitian berjudul survei minat dan motivasi masyarakat mengikuti fun race dan trail run di kawasan pariwisata Sembalun Lombok Timur di masa new normal.

\section{METODE PENELITIAN}

Jenis penelitian yang digunakan dalam penelitian ini adalah deskriptif, yang mendeskripsikan fenomena tertentu. Maksum (2012) bahwa apabila peneliti bermaksud mengetahui keadaan sesuatu mengenai apa dan bagaimana, berapa banyak, sejauh mana, dan sebagainya, maka penelitiannya bersifat deskriptif, yaitu menjelaskan atau menerangkan peristiwa. Pengambilan data menggunakan metode observasi (pengamatan), angket (kuosioner), interview (wawancara) dan dokumentasi. Hasil dari penelitian ini merupakan gambaran atau lukisan secara sistematis, faktual tentang fakta-fakta yang bersangkutan dengan minat dan motivasi masyarakat melakukan olahraga rekreasi dengan fun race dan trail run di kawansan wisata Sembalun Lombok Timur Nusa Tenggara Barat. 
Sumber data dalam penelitian ini adalah sumber yang sesuai dengan fungsi dan kewenangan yang dimiliki. Sumber data dalam penelitian masyarakat yang mengikuti olahraga rekreasi yakni fun race dan trail run di Sembalun Lombok Timur. Jumlah populasi dalam penelitian ini adalah masyarakat yang mengikuti event fun race dan trail run yang dilaksanakan pada masa new normal covid 19. Kemudian penelitian ini menggunakan teknik accidental sampling dengan jumlah sampel 50 orang. Analisis data merupakan bagian yang sangat penting dalam penelitian. Secara garis besar, pekerjaan analisis data meliputi 3 langkah yaitu persiapan, tabulasi dan penerapan data sesuai dengan pendekatan penelitian.

Pengumpulan data dalam penelitian ini menggunakan survei, wawancara dan angket. wawancara atau interview adalah suatu bentuk komunikasi verbal jadi semacam percakapan yang bertujuan untuk memperoleh informasi. Pengumpulan data dilakukan dengan wawancara dengan masyarakat tentang faktor apa yang mempengaruhi minat dan motivasi masyarakat mengikuti fun race dan trail run. Lembar observasi guna memperoleh bahan-bahan tambahan yang diperlukan diadakan peninjauan secara langsung diikuti dengan cermat. Hasilnya dicatat dan disusun menjadi laporan. Penelitian ini dilakukan pada saat kegiatan sedang berlangsung untuk mendapatkan kesimpulan.

Setelah melakukan wawancara maka selanjutnya diadakan analisis data. Catatanya dihasilkan berupa rekaman dan lembar observasi. Selanjutnya dideskripsikan ke dalam bentuk tulisan kemudian diolah dengan penafsiran-penafsiran yang dianalisis secara deskriptif sesuai dengan prosedur penelitian kualitatif bahwa analisis data adalah proses mengorganisasikan dan mengurutkan data ke dalam bentuk pola, kategori, satuan urutan dasar sehingga dapat ditemukan tema dan dapat dirumuskan hipotesis kerja yang disarankan oleh data.

\section{HASIL DAN PEMBAHASAN}

Dalam analisis data dan pembahasan penelitian minat dan motivasi fun race dan trail run di masa new normal di kawasan wisata Lombok Timur tahun 2020, berdasarkan data penyebaran angket yang peneliti lakukan. Berdasrkan tujuan penelitian yakni survei minat dan motivasi peserta mengikuti fun race dan trail run dari hasil perhitungan presentase minat dan motivasi peserta mengikuti fun race dan trail run setelah diberikan angket serta diolah dengan teknik statistik desktiptif. Data penelitian diperoleh berdasarkan jawaban sampel dimana terdapat faktor yang mempengaruhi minat dan motivasi masyarakat mengikuti fun race dan trial run akan di deskripsikan dari data keseluruhan maupun masing-masing faktor yang dilihat dari diagram dibawah ini.

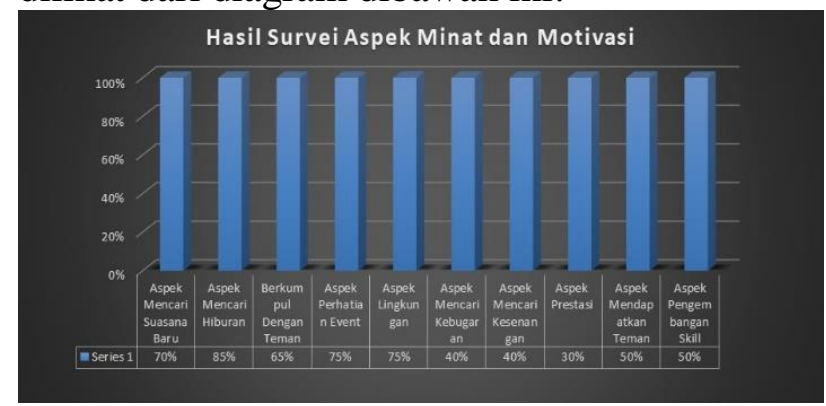

Berdasarkan gambaran hasil penelitian, dapat diketahui rata-rata masyarakat yang mengikuti fun race dan trial run adalah minat dan motivasi peserta yang mengikuti fun race dan trail run adalah aspek mencari suasana baru $70 \%$, aspek mencari hiburan $85 \%$, dan berkumpul dengan teman $65 \%$, aspek perhatian event $75 \%$, aspek lingkungan $75 \%$, aspek mencari kebugaran $40 \%$, mencari kesenangan $40 \%$, aspek prestasi $30 \%$, aspek mendapatkan teman 50\%, Aspek pengembangan skill 50\%.

Berdasarkan hasil angket dari beberapa sumber yang ada dapat ditarik kesimpulan bahwa minat dan motivasi masyarakat mengikuti fun race dan trial run dapat dikatakan sangat baik, ini disebabkan antusisias masyarakat mengikuti lomba sangat tinggi, tujuan utama dalam mengikuti lomba yakni 85\%. Hasil deskriptif data menunjukan masyarakat yang mengikuti fun race dan trial run di daerah pariwisata Sembalun Lombok 
Timur dalam kategori tinggi. Jadi dapat disimpulkan minat dan motivasi masyarakat mengikuti festival fun race dan trial run di masa pandemi covid 19 di kawasan pariwisata Sembalun Lombok Timur tergolong dalam kategori tinggi..

Memajukan olahraga harus bertumpu pada konsep pembinaan dan pengembangan, yaitu dilaksanakan dan diarahkan untuk memassalkan olahraga sebagai upaya mengembangkan kesadaran masyarakat dalam meningkatkan kesehatan, kebugaran, kegembiraan, dan hubungan sosial (Chu, 2018). Sebagai upaya menumbuhkan perkumpulan olahraga dalam masyarakat, serta menyelenggarakan festival olahraga rekreasi yang berjenjang dan berkelanjutan pada tingkat daerah, nasional dan internasional.

Pengembangan olahraga fun race dan trail run berpotensi besar sebagai daya tarik dan sarana promosi daerah dan peningkatan bibit atlet atlet Nusa Tenggara Barat. Demikian pula akan berdampak positif bagi daerah dan masyarakat serta usaha kecil dan menengah di daerah penyelenggaraan. Penyelenggaraan olahraga pariwisata disuatu tempat secara langsung dapat pula memberikan keuntungan bagi masyarakat sekitar karena dapat membuka kesempatan untuk penyediaan makanan, minuman, usaha transportasi baik tradisional maupun konvensional.

Produk dari industri olahraga, olahraga pariwisata memerlukan pengelolaan lebih lanjut agar mampu menarik minat wisatawan asing maupun lokal sebagai konsumennya. Pengelolaan tersebut harus direncanakan dengan baik, akan mampu memberikan dampak yang positif bagi pembangunan pariwisata di Lombok Timur dan pada akhirnya akan mampu mendorong peningkatan pariwisata. Pengembangan olahraga pariwisata yang semakin prospektif ke depan dan konstribusi pariwisata untuk pembangunan daerah. Kegiatan keolahragaan pada dasarnya tidak dapat terlepas dari kegiatan-kegiatan lainnya serta kehidupan masyarakat sehari-hari. Kegiatan keolahragaan sekarang ini sudah menjadi kebutuhan yang harus terpenuhi oleh manusia karena mampu memberikan tubuh menjadi lebih bugar dari pada sebelumnya. Olahraga akan memberikan dampak positif kepada pelaku olahraga karena aktivitas gerak yang diperoleh selama melakukan bermacam kegiatan olahraga akan memberikan kebugaran jasmaniah dan kepuasan rohaniah bagi tubuh (Daener, 2018). Kebugaran jasmaniah yang dimaksud adalah terjadinya perubahan kondisi fisik yang lebih baik terutama pada jantung, paru-paru, dan pembuluh darah sedangkan kepuasan rohaniah lebih menekankan kepada kepuasan bathiniah selama kegiatan olahraga itu dapat memberikan kesenangan untuk dirinya sendiri. Hubungan olahraga dan parawisata tidak dapat dipisahkan karena keduanya dapat memberikan keuntungan satu sama lain dalam mengembangkan sport tourism, sehingga perlunya pengembangan event olahraga di Nusa Tenggara Barat sebagai ikon sport tourism. Sehingga dapat diungkap secara mendalam proses pengembangan event olahraga fun race dan trail run menjadi peningkatan minat dan motivasi sebagai prestasi dan sport tourism tingkat nasional dan Internasional.

Masyarakat yang mengikuti festival sebenarnya sudah memiliki minat dan motivasi untuk melakukan olahraga rekreasi dikawasan Sembalun Lombok Timur Nusa Tenggara Barat. Masyarakat yang mengikuti festival mencari kesenangan, kebugaran, mendapat teman dan mencari pengalaman. Dengan adanya tujuan pada masyarakat ketika mereka datang tentunya akan membuat pemahaman yang menjadi dasar mereka untuk mengikuti festival fun race dan trail run, yang nantinya dapat dijadikan acuan bagi penyelenggaraan festival pada tahun berikutnya. kawasan Sembalun Lombok Timur merupakan sebuah alternatif pengembangan soprt tourism untuk dijadikan pengembangan festival olahraga di Nusa Tenggara Barat.

\section{KESIMPULAN}

Fun race dan trail run merupakan perlombaan yang ditunggu oleh masyarakat di masa covid 19, sebagai salah satu sarana untuk menghilangkan kebosananan setelah beberapa 
bulan berdiam diri di rumah. Dari hasil penelitian 50 sampel minat dan motivasi peserta yang mengikuti fun race dan trail run adalah aspek mencari suasana baru $70 \%$, aspek mencari hiburan $85 \%$, dan berkumpul dengan teman $65 \%$, aspek perhatian event $75 \%$, aspek lingkungan $75 \%$, aspek mencari kebugaran $40 \%$, mencari kesenangan $40 \%$, aspek prestasi $30 \%$, aspek mendapatkan teman 50\%, Aspek pengembangan skill $50 \%$.

\section{DAFTAR PUSTAKA}

Agus, Kristiyanto. 2012. Pembangunan Olahraga Untuk Kesejahteraan Rakyat dan Bangsa. Yuma Pustaka. Surakarta.

Chu, T,L. 2018. Motivational Processes in Sport Education Programs Among High School Students : A Sytematic Review. Erupaen Physical Educaton Review . Vol 24 (3) 372-394.

Daener, R.O., Balish, S.M. 2016. Sex Differences in Sport Interest and Motivation: an Eyolutionary: Perspective. Evolotionary Behavioral Sciences. Vol 10, No 2. 73-97.

Endrawan, I, B., Gunawan, F, A. 2017. Survei Motivasi Belajar Siswa Mata Pelajaran Pendidikan Jasmani Olahraga dan Kesehatan Melalui Permainan Tradisional. Jurnal Ilmiah Bina Edukasi, Vol 10, No 1. 13-22.

Firdaus, M., Kuriawan, W, P. 2019. Survei Minat dan Motivasi Mayarakat Melakukan Olahraga Rekreasi Melalui Program Car Free Day di Kota Kediri. Proceeding of The National Seminar, UTP 1-5.

Kodric, M., Sindik, J., Mandic, G, F., Svhifler.B. 2013. Participation Motivation and Student's Physical Activity Among Sport Students in Three Countries. Journal Of Sport Sciences and Medicine (12) 10-18.

Kustiawan, A, A. 2018. Memajukan Olahraga Rekreasi dan Even Olahraga Sebagai Upaya Meningkatkan Penjualan
Produk Industri Olahraga. Prosiding SNIKU Vol. 1 No 1, (74-82).

Lonsdale., Hodge K., Hagreaves, E,A., Johan, N.G., 2014. Comparing Sport Motivation Scales : A Response to Pelletier. Journal Psccology of Sport and Exercise.446-452.

Mutohir, Toho Cholik. (2012). Sport Tourism Industry:A Case of Indonesi. Paper presented at International Conference of Sport Industry; Tapping Economic Value of Sport Tourism, Denpasar, Bali.

Rahmawati, N, Hilman, Y, A., Triono, B. 2020. Peran Dinas Pariwisata Dalam Pengelolaan Wisata Minat Khusus di Kabupaten Ponorogo. Jurnal Ilmiah Pariwisata. Vol 25, No 1. 1-9.

Wibowo, T. 2017. Survei Motivasi Belajar Siswa Dalam Mengikuti Pembelajaran Jasmani, Olahraga dan Kesehatan Pada Siswa Kecamatan Kota Ponorogo. Jurnal Pendidikan Olahraga dan Kesehatan. Vol. 5 No 1. 117-122. 